\title{
The Upper Cretaceous-Paleogene of Phosphate Clays of the Ouled Bou Sbaa Deposit: Mineralogy, Geochemistry, and Beneficiation (Meskala, Morocco)
}

\author{
Hanane El Boukhari' ${ }^{1}$, Salem El Ouariti', Mustapha Mouflih', \\ Mohammed Amine Nguidi1, László Kocsis², Abdelmajid Benbouziane ${ }^{1}$ \\ ${ }^{1}$ Laboratory of Dynamic of Sedimentary Basins and Geological Correlations, Hassan II University of Casablanca, Casablanca, Morocco \\ ${ }^{2}$ Faculty of Science, University Brunei Darussalam, Geology Group, Gadong Brunei Darussalam, Brunei \\ Email: hanane.elboukhari-etu@etu.univh2c.ma
}

How to cite this paper: El Boukhari, H., El Ouariti, S., Mouflih, M., Nguidi, M.A., Kocsis, L. and Benbouziane, A. (2022) The Upper Cretaceous-Paleogene of Phosphate Clays of the Ouled Bou Sbaa Deposit: Mineralogy, Geochemistry, and Beneficiation (Meskala, Morocco). Open Journal of Geology, 12, 156-178.

https://doi.org/10.4236/ojg.2022.122008

Received: January 3, 2022

Accepted: February 25, 2022

Published: February 28, 2022

Copyright $\odot 2022$ by author(s) and Scientific Research Publishing Inc. This work is licensed under the Creative Commons Attribution International License (CC BY 4.0).

http://creativecommons.org/licenses/by/4.0/

\begin{abstract}
This work aims first to characterize the Maastrichtian and Paleogene clays of the Ouled Bou Sbaa phosphate deposit located in the northern part of the Meskala Basin; and as a second goal, the most efficient clay fractions are tested and identified for organic dyes removal. Several techniques and methods have been adopted for the characterization of clays: X-ray diffraction (XRD), Fourier transform infrared spectroscopy (FTIR), X-ray fluorescence (XRF), Scanning electron microscope (SEM), and thermogravimetric analysis (TGA). Tests for the removal of methylene blue from clays were carried out by adsorption. The XRD study shows that the clays of the Ouled Bou Sbaa deposit contain fibrous clay types of palygorskite and sepiolite, and phyllite clays such as montmorillonite and illite. Stratigraphically, the Maastrichtian sample yielded, mainly aluminous clays dominated by montmorillonites, while in the Paleogene clays, the palygorskite-types clays, also rich in magnesium, are more common. The results of FTIR, XRF and SEM analyses confirm the mineralogical data, respectively, by the presence of characteristic bands and the dominance of oxides of silica, aluminum, magnesium, and the large dominance of palygorskite which is presented in the form of bundles or platelets of long fibers and montmorillonite which is presented in the form of a stack of sheets. The adsorption of methylene blue (MB) on these clays showed very fast fixation kinetics and a very efficient purifying power for this organic pollutant. The equilibrium isotherms were determined using the Langmuir, Freundlich and Elovich models. The results show that the Freundlich isotherm had better agreement with the methylene blue on clay with a correlation coefficient of 0.959 .
\end{abstract}




\section{Keywords}

Phosphate Clays, Palygorskite, Beneficiation, Meskala Basin

\section{Introduction}

The textile industry is the main source of waste dyes in aquatic systems [1] [2]. These dyes are highly toxic and present a risk to the life of many organisms. Human exposure to this dye family causes skin irritation, gastric disorders, eczema and breathing difficulties [3]. Basic dyes such as methylene blue (MB) also pose a significant threat to human health [4]. Several techniques are used to treat and remove heavy metal contaminants found in water. Adsorption is one of the most adopted techniques for the elimination of pollutants in our environment because of its great capacity to purify contaminated water. Indeed, clays are among the industrial minerals which have an economic value and whose physical or chemical properties [5] [6] are used in various applications as materials for the elimination of dyes and pollutants [7] from the waters of mining and urban sites in order to protect the environment effectively and sustainably. Dyes adsorption on clays is generally attributed to an ion exchange mechanism and linked to the surface specific area of the adsorbent [8] [9].

The Moroccan phosphate series shows the highest phosphate concentrations in terms of quality and quantity. This wealth makes Morocco the world leader in the production and exploitation of phosphates in all its forms. The Meskala Basin is one of Morocco's phosphate basins. It is the first of the large phosphate complexes from the Atlas border to the north. This basin is characterized by a phosphate series of Upper Cretaceous-Paleogene age and three deposits: Ouled Bou Sbaa, IminTanout and Khemiss Meskala. In addition to this richness, we also have other natural materials that are as important in quantity as in quality. These are clayey and marly sediments intercalated and/or associated with phosphate deposits. This study focused on the evaluation of the clays from the Ouled Bou Sbaa deposit as raw materials in various applications (water treatment) by studying their mineralogical properties by X-ray diffraction (XRD) and Fourier transform infrared spectroscopy (FTIR), their chemical properties by X-ray fluorescence (XRF), their textural properties by scanning electron microscope (SEM) and their thermal properties by thermogravimetric analysis (TGA). The adsorption characteristics of the adsorbent were also determined to evaluate its ability to remove methylene blue.

\section{Materials and Methods}

\subsection{Study Areas}

The Essaouira Basin is located in central-western Morocco. The "onshore" Essaouira Basin is the central element of the large Mesozoic coastal basin of El Ja- 
dida-Agadir [10] or the "basin of south-west Morocco" [11]. It is bordered to the north by the Doukkala Basin [12] [13], to the north-east and east by the sills of the Western Jebilet and Haouz, and to the south by the Agadir Basin (now the Western High Atlas). Towards the west, the basin opens up to the Atlantic Ocean. The Essaouira Basin underwent several tectonic phases. These are related to the opening of the Atlantic Ocean during the early Jurassic (Lias) and to the alpine orogeny [14]. This basin is characterized by a series of monoclinals separated by zones with steep dips. This structuring allowed the outcrop of Mesozoic deposits [15]. The Ouled Bou Sbaa deposit is part of the large onshore Essaouira Basin precisely in the region of Chichaoua (Figure 1) at about $7 \mathrm{~km}$ and $70 \mathrm{~km}$ west of the city of Marrakech.

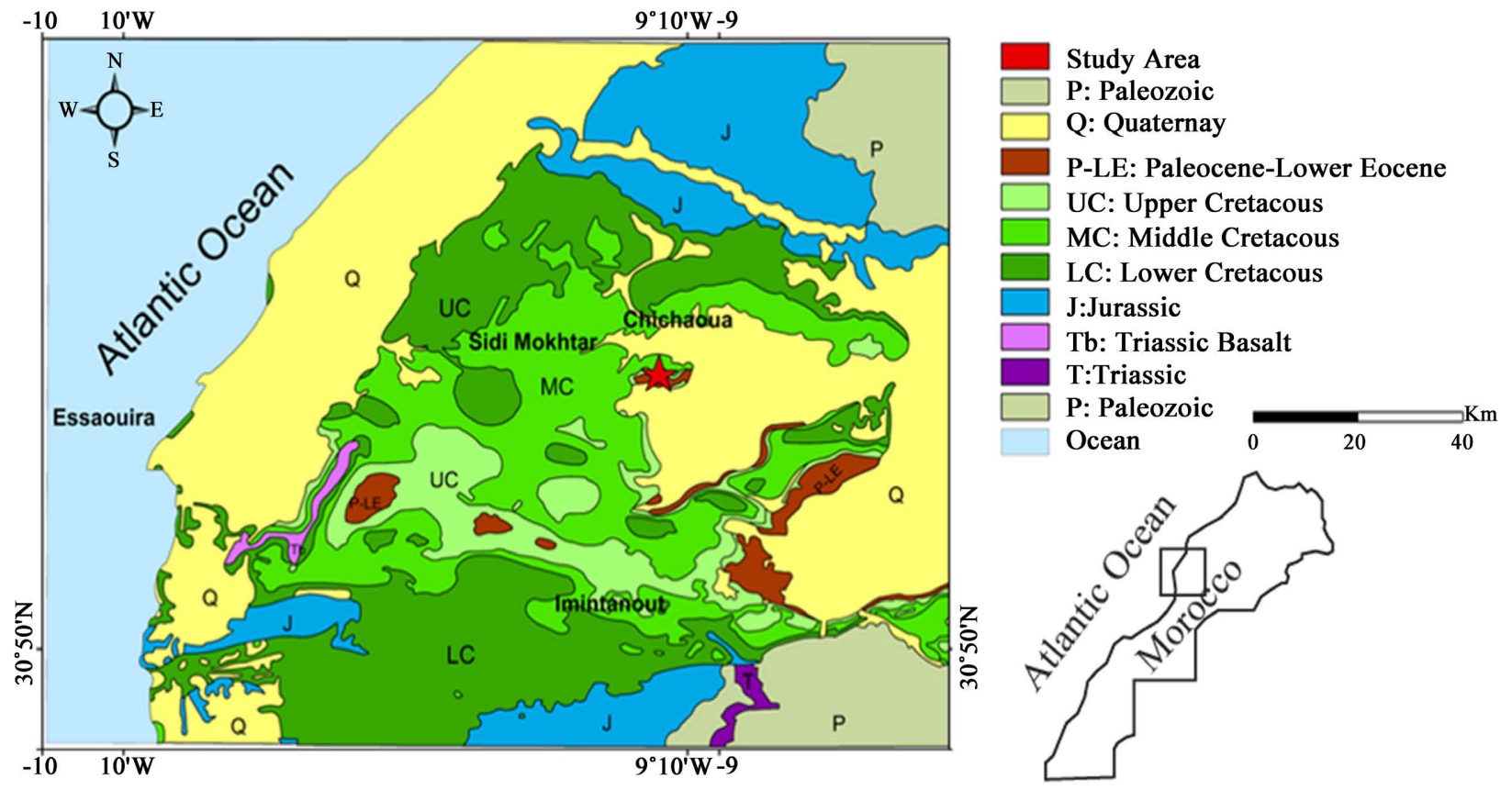

Figure 1. Geological setting of the Ouled Bou Sbaa deposit.

\subsection{Sampling}

A field mission was carried out in the Ouled Bou Sbaa deposit (Meskala Basin) in which a sedimentary logs were recorded (Sidi Mokhtar section) and a systematic sampling (18 samples named CHSM) of intercalary clays and/or those associated with the phosphate deposits were carried out.

\subsection{Analyses}

The clayey sediments associated or intercalated with the phosphate deposits of the Ouled Bou Sbaa deposit often, contain carbonate and organic matter impurities. These were removed by washing under a $50 \mu \mathrm{m}$ sieve and then attacked respectively by $5 \%$ hydrochloric acid and hydrogen peroxide (Sigma Aldrich). Then the mixture was washed with distilled water until the liquid overlying the base remained opalescent. The clay, suspended in water, was then recovered in 
the first few centimeters by decanting after centrifugation. This operation made it possible to have granulometric fractions with a size of less than $2 \mu \mathrm{m}$. The preparations of the treated $<2 \mu \mathrm{m}$ fraction were analyzed by two methods. The first method was from disoriented powders, and the second method was from deposit on a surface of glass slides treated by saturation with ethylene glycol (Sigma Aldrich) for 24 hours and heated at $490^{\circ} \mathrm{C}$ for 2 hours. A Philips PANalytical XRD apparatus (serial number: DY2042) was used to analyze the all samples. It is equipped with $\mathrm{Cu} \mathrm{X}$-ray radiation source $(\mathrm{K} \alpha 1=1.5406 \AA)$ operating at a voltage of $45 \mathrm{kV}$ and current of $40 \mathrm{~mA}$. The data were recorded from $5^{\circ}$ to $70^{\circ} 2 \theta$ and evaluated with X'Pert High Score Plus software package (PANalytical_2004) at the X-ray diffraction laboratory of the UATRS of the national center for scientific and technical research (CNRST) in Rabat. In addition the all samples were measured with Fourier transform infrared spectroscopy (FTIR), using a Perkin Elmer spectrometer equipped with an ATR-FTIR module in the range of $4000-400 \mathrm{~cm}^{-1}$ with $4 \mathrm{~cm}^{-1}$ resolution. Major element compositions of the clay minerals were obtained by X-ray florescence (XRF) analyses using an Epsilon 3XL type spectrometer. Powders were first heated at $105^{\circ} \mathrm{C}$ under nitrogen to drive off adsorbed $\mathrm{H}_{2} \mathrm{O}$, before being ignited at $1000^{\circ} \mathrm{C}$ under oxygen to drive off remaining volatiles and oxidize Fe. Thermo-Gravimetric Analysis (TGA) consists of monitoring the mass loss of clay as a function of the heating temperature in relation to a reference as a function of the heating time using a thermogravimetric analyzer type Setsys Ev 1750. The clays samples had undergone a heat treatment from $45^{\circ} \mathrm{C}$ to $850^{\circ} \mathrm{C}$ degrees with a constant heating rate of 20 ${ }^{\circ} \mathrm{C} / \mathrm{min}$. The mass used for each sample ranges from 16 to $57 \mathrm{mg}$. The morphology of the clay fractions was observed in detail with a Hirox SH-4000MB scanning electron microscope (SEM) at the Ain Choq Faculty of Science. The clay powders were glued to double-sided carbon tape, then metallised by depositing a carbon surface film for observation with a scanning electron microscope. Batch adsorption experiments were performed in a set of Erlenmeyer flasks $(250 \mathrm{ml})$, each of which contained $100 \mathrm{~mL}$ of different MB concentrations (50 - $100 \mathrm{mg} / \mathrm{l}$ ) along with $50 \mathrm{mg}$ of adsorbent. An orbital shaker was introduced at a desired temperature and $\mathrm{pH}$. To reach steady-state adsorption, a time contact equal to 90 min was set for all experiments. Adsorbate concentrations were determined by a UV-Visible $10001 \mathrm{C}$ spectrophotometer at $664 \mathrm{~nm}$. The amount of Metylene Blue adsorbed per unit mass on clay was calculated according to Equation (1):

$$
q=V\left(C_{0}-C_{e}\right) / m
$$

where $C_{0}$ and $C_{e}$ are the initial and equilibrium (after adsorption) concentrations of the Methylene Blue solution (mg. $\mathrm{L}^{-1}$ ), respectively. $V$ is the volume of the methylene blue solution $(I)$, and $\mathrm{m}(g)$ represents the mass of the clay. To study the adsorption isotherm, $0.05 \mathrm{~g}$ of clay was added to $100 \mathrm{ml}$ of methylene blue solutions of different concentrations (50 - $\left.100 \mathrm{mg} \cdot \mathrm{L}^{-1}\right)$ during the equilibrium time. 


\section{Results}

\subsection{Lithostratigraphy and Description of the Facies Studied}

The recorded lithological section of 70 meters of Maastrichtian-Thanetian age in the Ouled Bou Sbaa deposit (Meskala Basin), is located in the north of Ouled Bou Sbaa, about $7 \mathrm{~km}$ from the village of Chichaoua. The succession is characterized by four sequences that are described below (Figure 2):

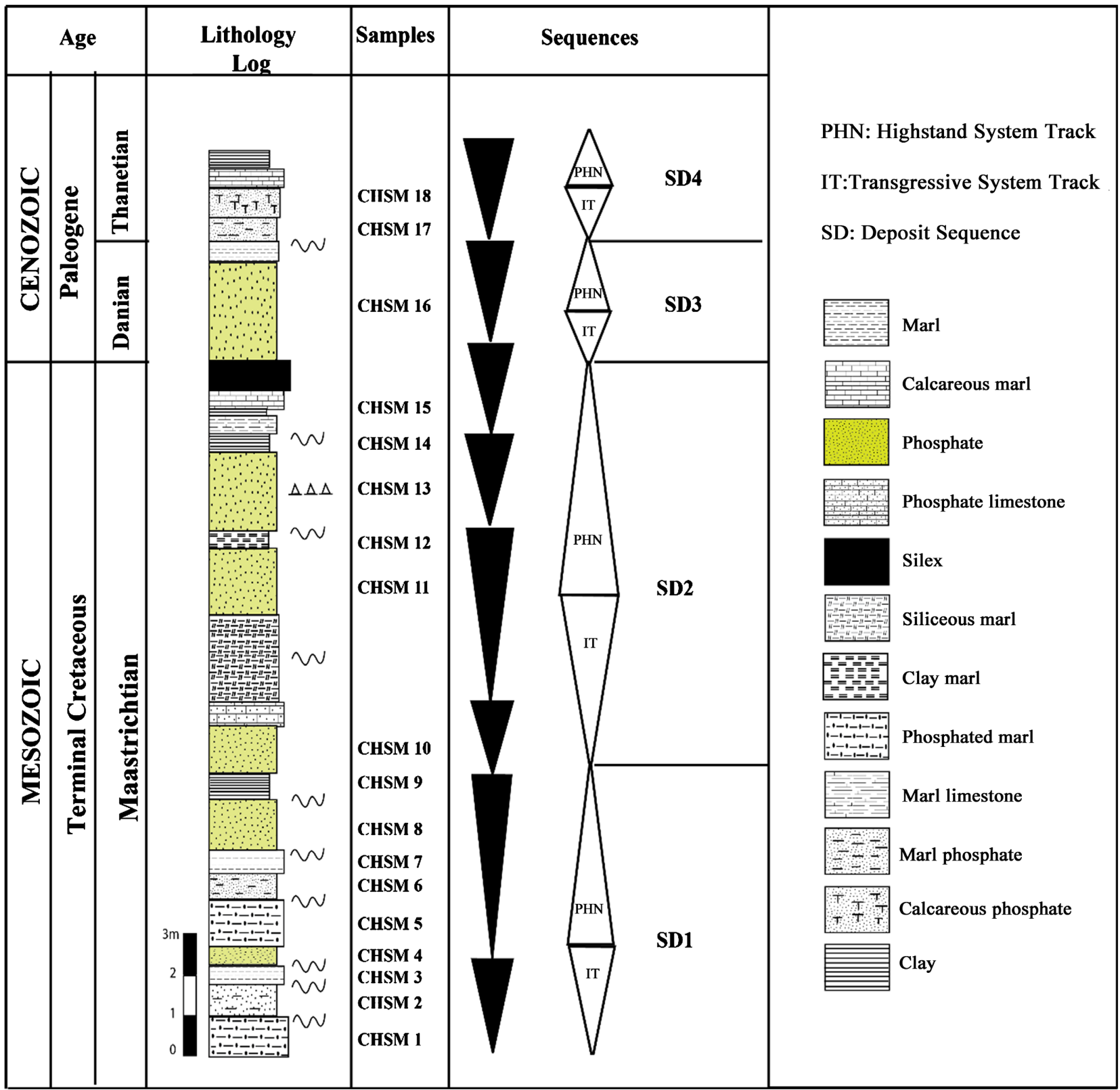

Figure 2. Lithostratigraphic section of the Ouled Bou Sbaa deposit.

\section{$1^{\text {st }}$ Maastrichtian sequence}

It begins with $1 \mathrm{~m}$ thick, yellowish phosphate marl, with intense bioturbation (Figure 3(A)). The bases of the phosphate layers (Figure 3(B)) are often ravined 
and marked by bioturbation. This sequence is capped by a $60 \mathrm{~cm}$ thick yellowish clay bioturbated at the base, which represents the boundary between the first sequence and the second sequence (benchmark level).

$2^{\text {nd }}$ Maastrichtian sequence contains 3 elementary sequences:

- The first begins with a very thick level of $1.2 \mathrm{~m}$ phosphate surmounted by a $40 \mathrm{~cm}$ thick, hard phosphate limestone bench.

- The second starts with a phosphatic limestone, overlain by a very thick, yellowish siliceous marly facies of $2 \mathrm{~m}$, followed by a greyish friable phosphatic level (Figure $3(\mathrm{C})$ ) of $1.6 \mathrm{~m}$ on which rests a $40 \mathrm{~cm}$ thick reddish clayey marl.

- Above this, a $1.7 \mathrm{~m}$ thick phosphatic level comes which is rich in fish teeth, then this elementary sequence is capped by a $40 \mathrm{~cm}$ thick reddish marl with bioturbation at its top.

- The third elementary sequence begins with a hard reddish marly facies, followed by a $40 \mathrm{~cm}$ thick limestone bench and end with a $70 \mathrm{~cm}$ thick flint (Figure 3(D)). The latter represents the boundary between the Maastrichtian and Tertiary (KT). This discontinuity is marked on the top of the layer by a blackish silica slab that is strongly bioturbated and filled with siliceous phosphate.

Danian sequence: It starts with a very thick phosphate level of $2 \mathrm{~m}$ that is altered at the top. This phosphate level is overlain by a hard $50 \mathrm{~cm}$ thick reddish marly facies with bioturbation on the top (Figure 3(E)).

Thanetian sequence: It begins with a $40 \mathrm{~cm}$ thick marly phosphate level, surmounted by a calcarinite phosphate, which is covered by $30 \mathrm{~cm}$ thick marl with a calcite geode and bioturbation. This level topped by a limestone bench with nodules. The phosphate series of the Ouled Bou Sbaa deposit ends with a highly altered clayey facies on the top (Figure 3(F)).

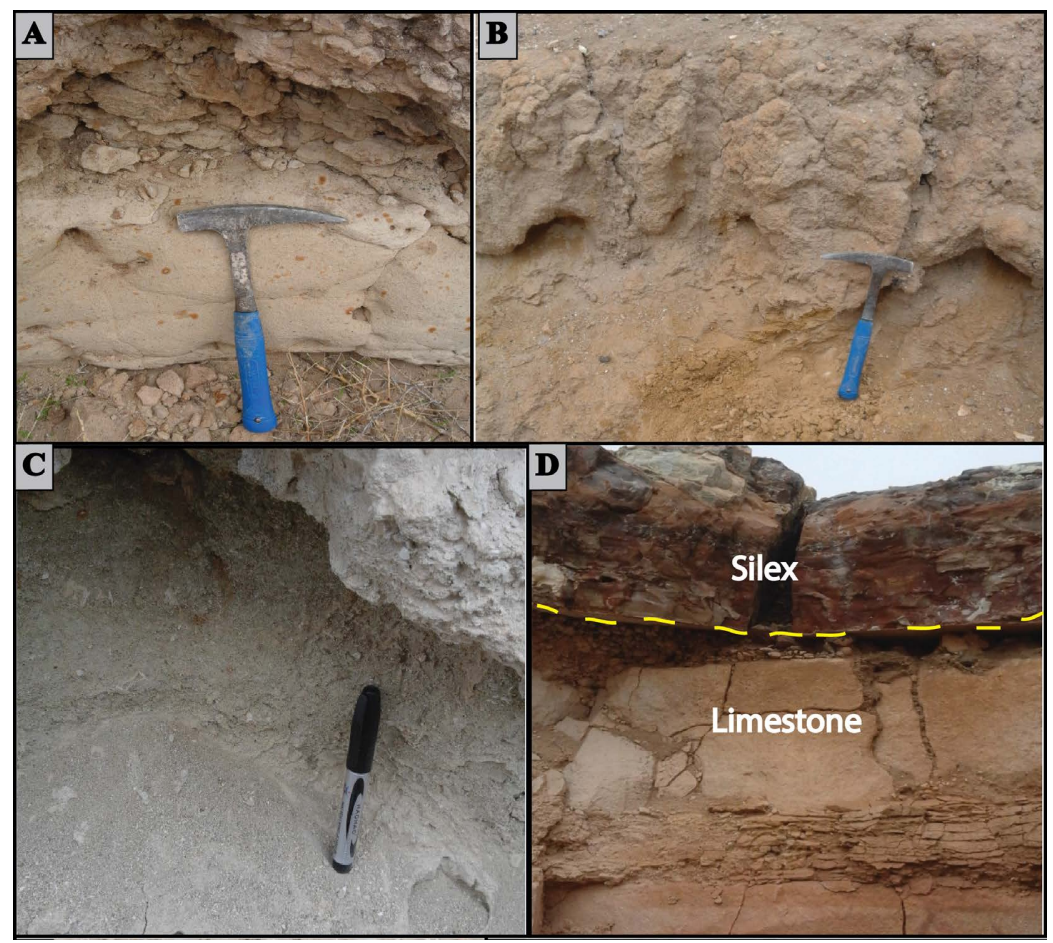




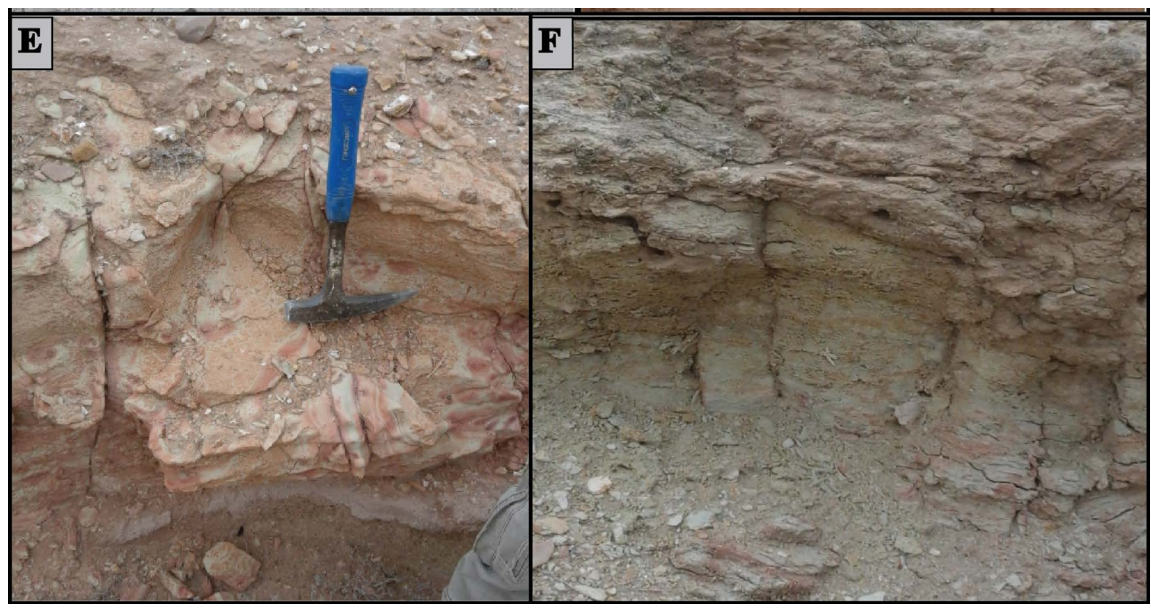

Figure 3. (A) Yellowish phosphate marl with intense bioturbation. (B) Yellowish friable phosphate. (C) Greyish friable phosphate level. (D) Boundary KT. (E) Hard reddish marly facies. (F) Clayey facies with intense alteration.

\subsection{Clay Mineralogy and Geochemistry Studied}

\subsubsection{X-Ray Diffraction}

All diffractograms reveal four main phyllosilicate minerals in the clays of the Ouled Bou Sbaa deposit (Figure 4): montmorillonite, palygorskite, sepiolite and illite. Palygorskite-type clays are found at $10.47 \AA$ and $10.50 \AA$, montmorillonite-type clays at $15 \AA$ and $15.37 \AA$, and illites at $4.48 \AA$. The distance at $12.47 \AA$ corresponds to the presence of sepiolites while the presence of quartz is indicated by $\mathrm{d}=3.34 \AA$ and $\mathrm{d}=4.24 \AA$ (Figure 4).

Figure 5 shows the superposition of the X-ray spectra obtained from the oriented slides of the clay fraction after saturation with ethylene glycol for $24 \mathrm{~h}$ or heated to $490^{\circ} \mathrm{C}$.

During the treatment with ethylene glycol, all samples show that the line recorded at $15 \AA$ increases to $17.1 \AA$, this indicates that the clays of the Ouled Bou Sbaa deposit are rich in montmorillonite-type clays. Reflections at $12.4 \AA$, 10.30 $\AA$, and $6.44 \AA$ confirmed the presence of fibrous phyllosilicates. The $12.4 \AA$ distance corresponds to sepiolite, while the $10.30 \AA$, $6.44 \AA$ distance is typical for palygorskite clay. The persistence of a peak around $10 \AA$ on all the diffractograms confirmed the presence of illite [16] [17], which is confirmed by the peak at $3.33 \AA$, which did not undergo any displacement following treatment with ethylene glycol and after heating. Quartz and carbonate fluoroapatite appear to be the minor mineral phases associated with the clays studied.

Semi-quantitative estimates based on the ratios of peak intensities of different mineral species indicate that the clays of the Bou Sbaa deposit are composed of about $80 \%$ phyllosilicate fraction (montmorillonite, palygorskite, sepiolite and illite see Figure 6) and 20\% non-clay minerals (quartz and carbonate fluoroapatite).

\subsubsection{Infrared Spectroscopy}

The infrared spectroscopy (IR) data of all clays of the Ouled Bou Sbaa show several absorption bands (Figure 7). The bands observed between 3432 and $3465 \mathrm{~cm}^{-1}$ 


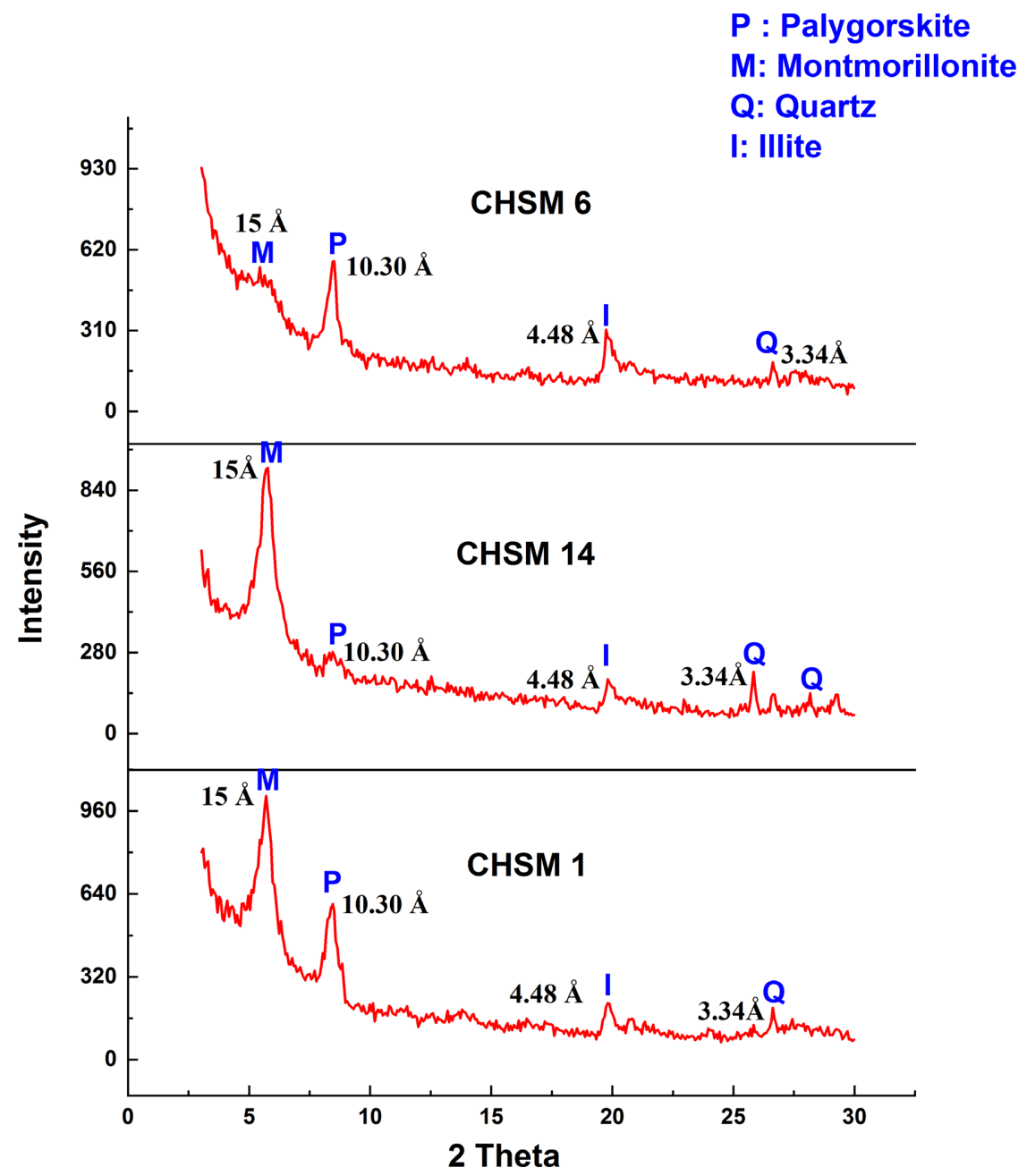

Figure 4. Selected X-ray diffractograms from the Ouled Bou Sbaa deposit showing the dominant clay minerals.

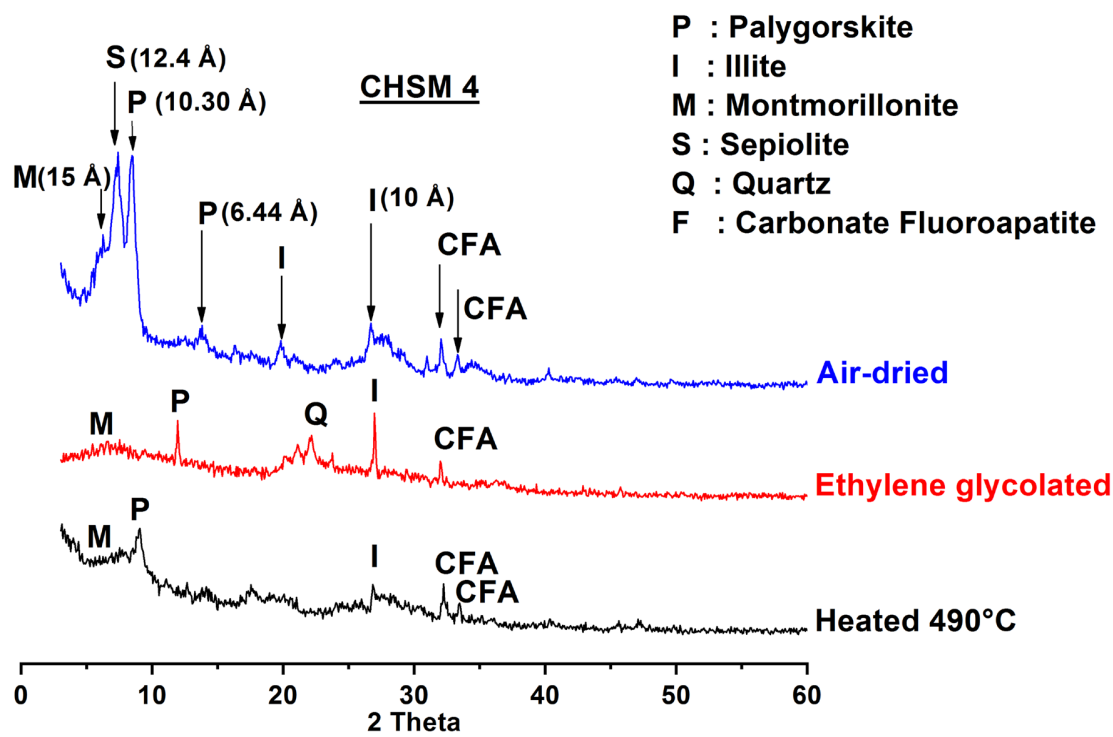

Figure 5. X-ray diffractograms of clays obtained from oriented samples under treatments from the Ouled Bou Sbaa phosphate deposit. 


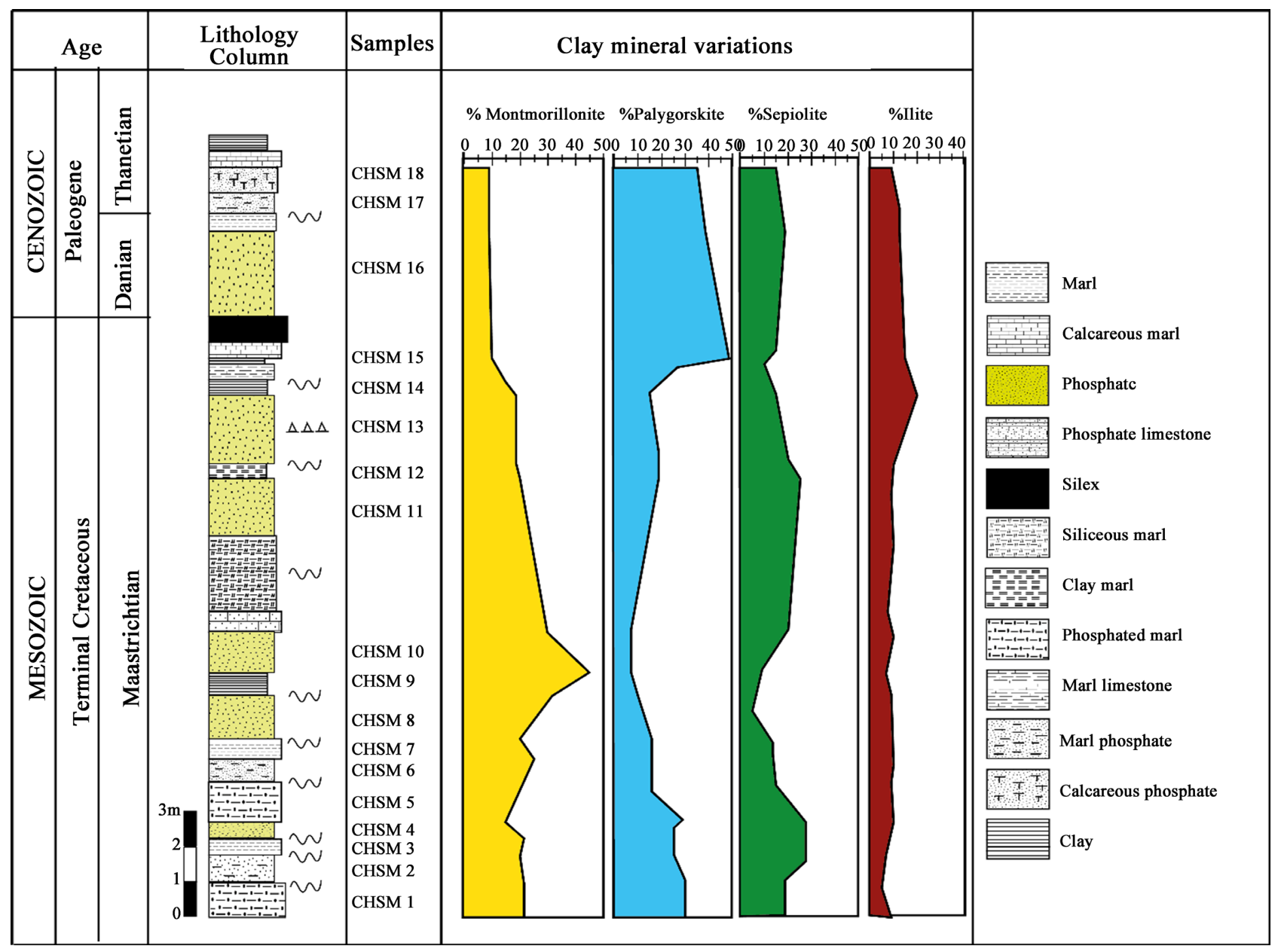

Figure 6. Mineralogical variation of clays in the phosphate series of the Bou Sbaa deposit.

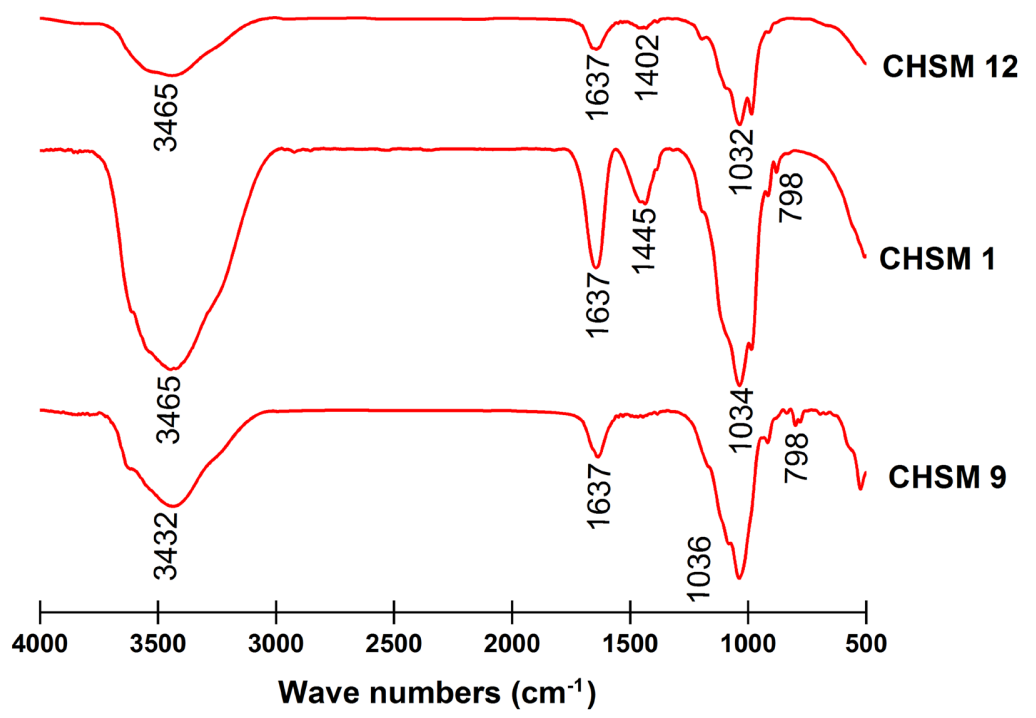

Figure 7. Selected infrared spectra of clays from the Ouled Bou Sbaa deposit.

correspond to the vibrations of the $\mathrm{OH}$ groups of the water absorbed between the clay sheets. These bands are characteristic of hydrophilic materials and are 
specific to montmorillonites [18] [19]. Bands at 1631 and $1637 \mathrm{~cm}^{-1}$ are attributed to deformation vibrations of the $\mathrm{O}-\mathrm{H}$ bond in water constitution [20], confirming the presence of montmorillonites [21] [22]. The bands at 1032, 1036 and $798 \mathrm{~cm}^{-1}$ : are attributed to valence vibrations of the $\mathrm{Si}-\mathrm{O}$ bond. They are manifested by shoulders that we attribute to the presence of quartz. These results are consistent with those of the XRD.

\subsubsection{Thermogravimetric Analysis}

The thermo-gravimetrique/Difference thermo-gravimetrique (ATG/DTG) curves (Figure 8) showed two main endothermic peaks: the first peak, between 50 and $250^{\circ} \mathrm{C}$, corresponds to the water loss and indicates the departure of surface water. This departure is confirmed by the loss of mass of about $15 \%$ in this temperature range. The second peak, between $400^{\circ} \mathrm{C}$ and $810^{\circ} \mathrm{C}$, accompanied by a mass loss of $11 \%$, is due to dehydroxylation of the clay. The high intensity of this seconde peak indicates the presence of a swelling phase (montmorillonite) [23] [24] interbedded with a non-swelling phase (illite) [25].

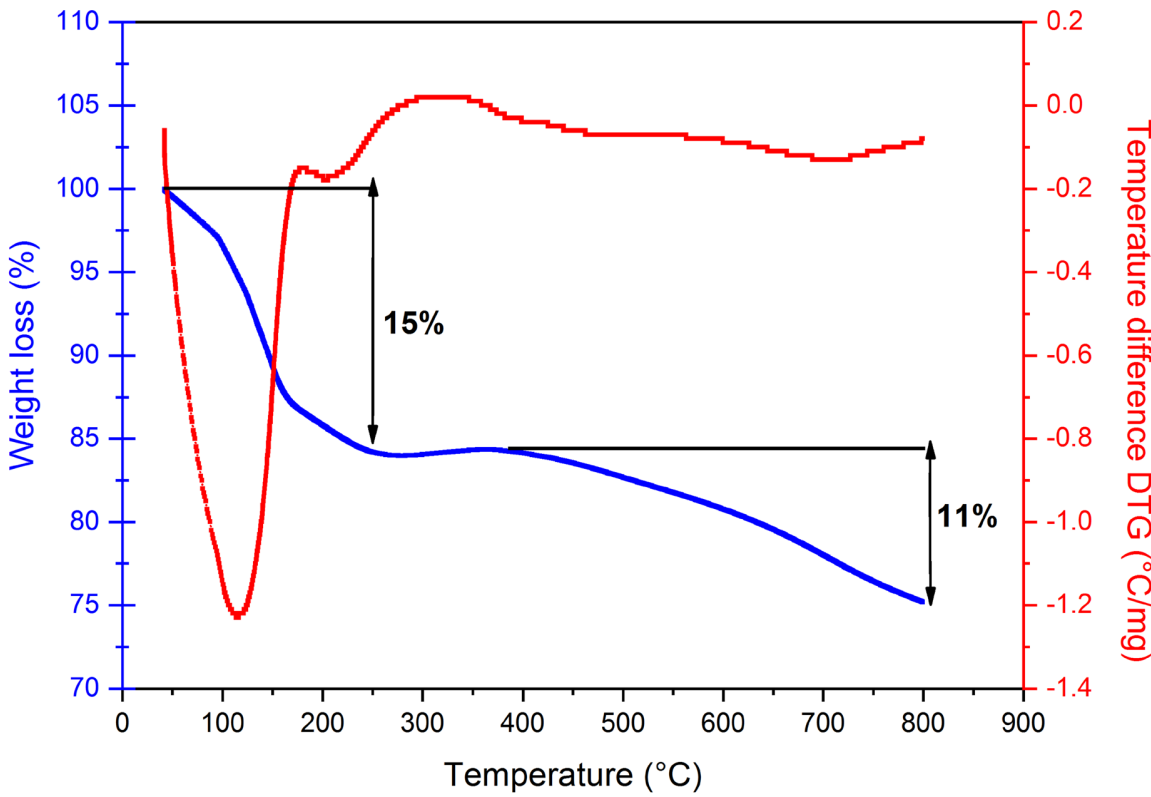

Figure 8. Thermogravimetric analysis curves of clays from the Ouled Bou Sbaa phosphate deposit.

\subsection{X-Ray Fluorescence}

The results of the quantitative chemical analysis of the major element oxydes ( $\mathrm{SiO} 2, \mathrm{Al}_{2} \mathrm{O}_{3}, \mathrm{MgO}, \mathrm{CaO}, \mathrm{Fe}_{2} \mathrm{O}_{3}, \mathrm{P}_{2} \mathrm{O}_{5}, \mathrm{TiO}_{2}, \mathrm{~K}_{2} \mathrm{O}$ ) of the clays of the Ouled Bou Sbaa deposit indicate that the predominant constituents are $\mathrm{SiO}_{2}, \mathrm{Al}_{2} \mathrm{O}_{3}, \mathrm{CaO}$, $\mathrm{MgO}$ and $\mathrm{K}_{2} \mathrm{O}$ which is consistent with the mineralogy data (Table 1). Silica and alumina reveal the presence in remarkable proportions of aluminosilicates such as montmorillonite. Magnesium ( $\mathrm{MgO})$ confirms the presence of magnesian montmorillonite and palygorskite clays. The potassium $\left(\mathrm{K}_{2} \mathrm{O}\right)$ indicates the presence of illite. Iron oxide, $\mathrm{Fe}_{2} \mathrm{O}_{3}$, is the main coloring agent in clay materials, 
being responsible for the reddish color after firing [26]. According to Table 1, the samples analyzed have a relatively high amount of $\mathrm{Fe}_{2} \mathrm{O}_{3}$, which gives the clay material a darker color after firing.

Table 1. The major element composition of the clays of the Ouled Bou Sbaa deposit.

\begin{tabular}{lccccccccc}
\hline & $\mathrm{SiO}_{2}$ & $\mathrm{Al}_{2} \mathrm{O}_{3}$ & $\mathrm{MgO}$ & $\mathrm{CaO}$ & $\mathrm{Fe}_{2} \mathrm{O}_{3}$ & $\mathrm{P}_{2} \mathrm{O}_{5}$ & $\mathrm{TiO}_{2}$ & $\mathrm{~K}_{2} \mathrm{O}$ & Loss on ignition \\
\hline CHSM 1 & 31.35 & 7.34 & 4.372 & 5.95 & 9.01 & 0.91 & 0.92 & 0.90 & 35.13 \\
CHSM 3 & 34.13 & 7.62 & 6.33 & 5.99 & 7.34 & 2.99 & 0.77 & 1.34 & 32.84 \\
CHSM 4 & 40.93 & 8.79 & 3.30 & 3.83 & 9.33 & 4.77 & 1.07 & 2.37 & 25 \\
CHSM 6 & 35.32 & 6.701 & 5.569 & 9.531 & 6.791 & 3.104 & 0.809 & 1.682 & 35.13 \\
\hline
\end{tabular}

\subsection{Scanning Electron Microscope (SEM)}

The images taken by the scanning electron microscopy of the clay samples of the deposit of Ouled Bou Sbaa with different magnifications are reported in Figure 9. The SEM observations confirmed the data of the mineralogical analysis, we note the large dominance of palygorskite which is presented in the form of bundles or platelets of long fibers oriented in a random way (Figures 9(B)-(D)), we also find montmorillonite which is presented in the form of a stack of sheets (Figure $9(\mathrm{~A}))$.

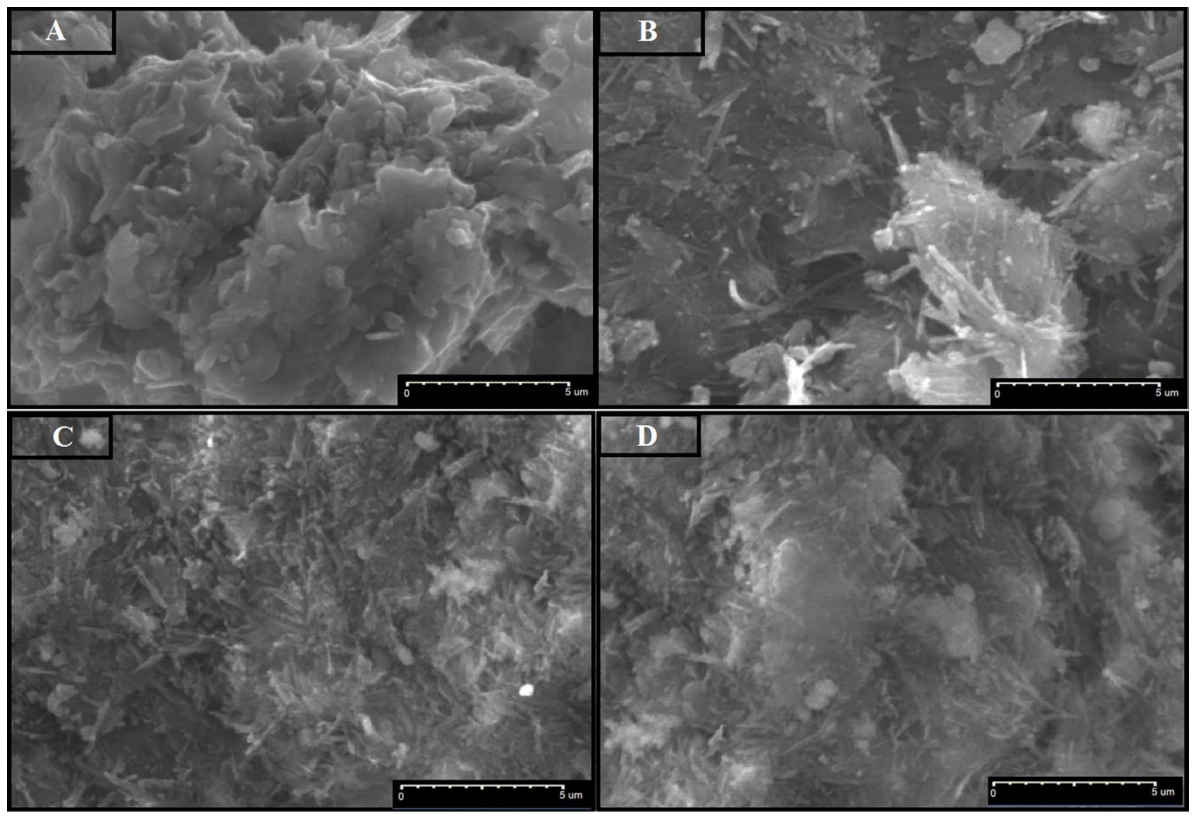

Figure 9. SEM images of the Ouled Bou Sbaa deposit. (A) Stacking of montmorillonite sheets, (B)-(D) Palygorskite fibers.

\subsection{Beneficiation Tests}

Heavy metals are typical pollutants in water from mining and urban sites. Several processes have been used to treat wastewater, including electrolysis, flotation, precipitation, and adsorption. The latter is considered to be the most efficient tech- 
nique for eliminating pollutants. For this reason, methylene blue was chosen as a representative model of a medium-size pollutant which has a large number of studies on its adsorption properties on solids [27]. Therefore, it was used to characterize the clays of the Ouled Bou Sbaa deposit. We studied the effect of contact time, methylene blue concentrations and clay mass on the sorption of methylene blue.

\subsubsection{Adsorption Kinetics}

The adsorption kinetics study is used to determine the contact time required to reach equilibrium. This study is carried out by determining the evolution of the adsorption yield as a function of time. The results obtained are shown in Figure 10 , which represents the variation of the methylene blue sorption efficiency as a function of the contact time.

The curve in the figure shows that at the beginning of agitation, the sorption yield of methylene blue is very fast and becomes slower and slower until the sorption equilibrium is reached.

This study showed that the maximum adsorption is reached with a percentage of about $99 \%$ and that the 90 min stirring time is sufficient to reach the methylene blue sorption equilibrium by our clay. These results agree with previous studies which have shown that adsorption equilibrium was reached rapidly [28] [29], however the clay of the Ouled Bou Sbaa deposit exhibited a higher uptake of methylene blue. From these data, we selected a contact time of 90 min for all adsorption experiments.

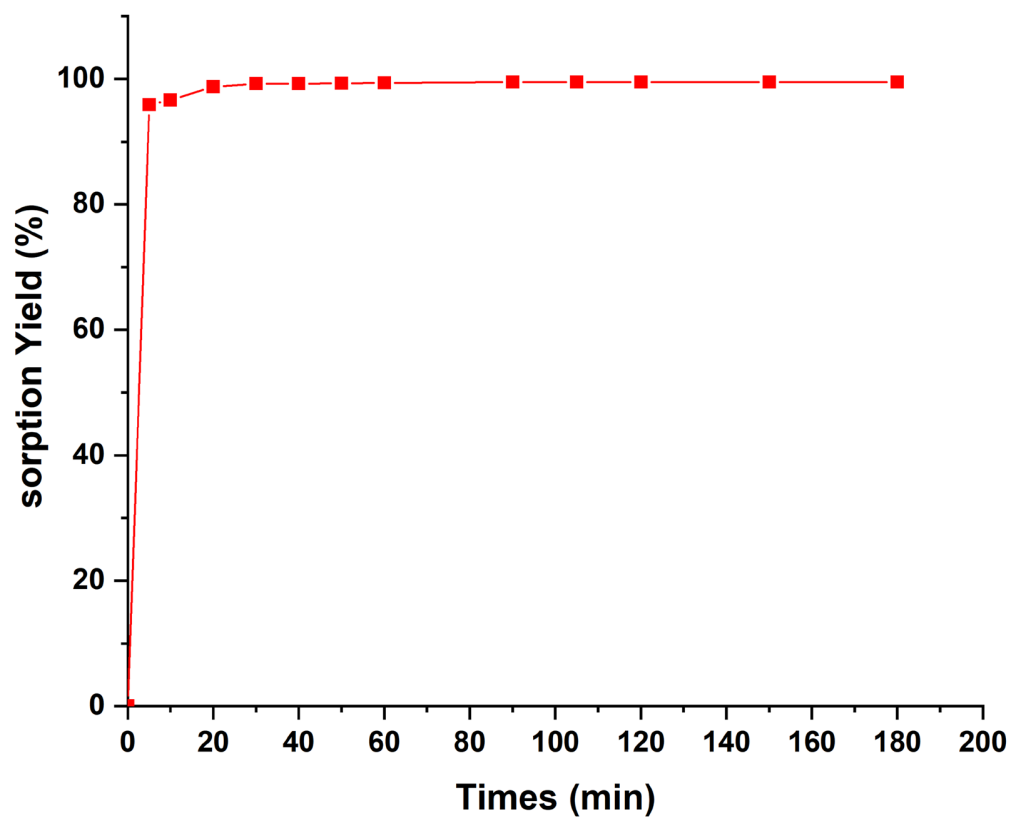

Figure 10. Kinetic study of the adsorption of methylene blue onto clay of the Ouled Bou Sbaa deposit.

\subsubsection{Influence of Methylene Blue (MB) Concentration}

The results of the adsorption of the methylene blue onto clay of the Ouled Bou Sbaa deposit at different concentrations are shown in Figure 11. The results ob- 
tained show that the adsorption efficiencies, after equilibrium, decrease as the initial concentration increases, the efficiency decreasing at its maximum for a concentration of $60 \mathrm{mg} / \mathrm{l}$. The best adsorption yields are reached in $90 \mathrm{~min}$.

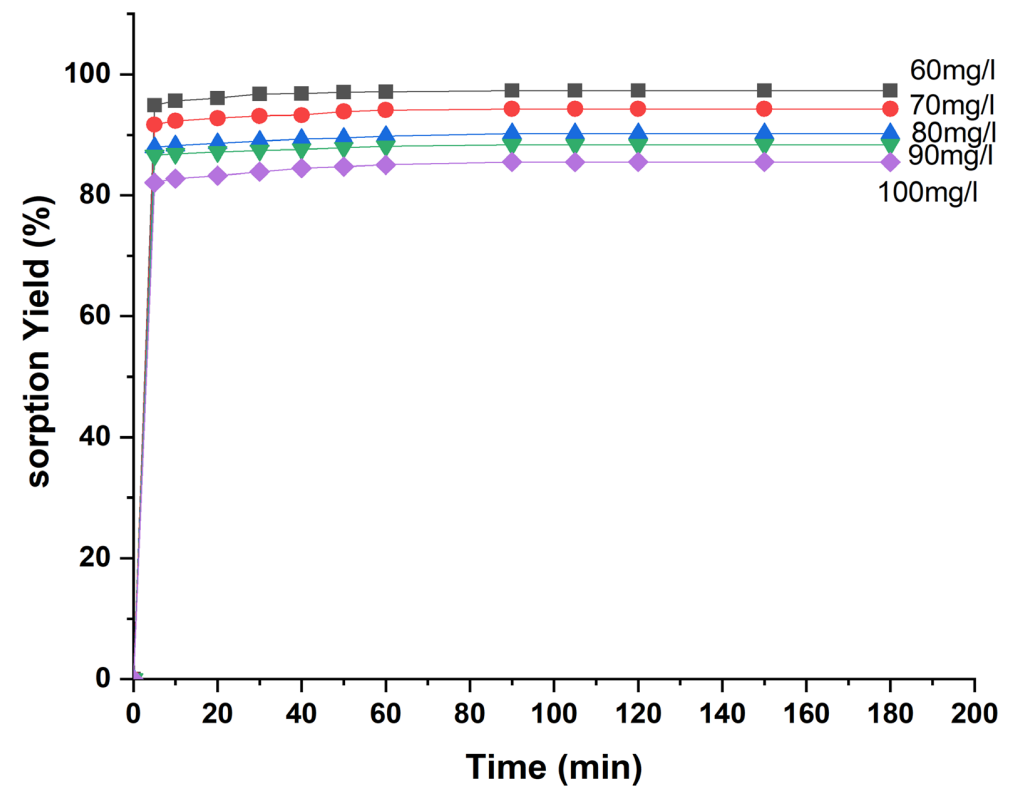

Figure 11. Effect of concentration on adsorption methylene blue on clay.

\subsubsection{Influence of Clay Mass on MB Sorption}

To study the influence of the clay mass a series of experiments were conducted for various clay masses $(0.02 ; 0.03 ; 0.04 ; 0.1$ and $0.2 \mathrm{~g})$ each mass is brought into contact with $50 \mathrm{ml}$ of methylene blue solution with a concentration of $100 \mathrm{mg} / \mathrm{l}$ with constant agitation during the equilibrium time.

The curve in Figure 12 expresses the evolution of methylene blue sorption

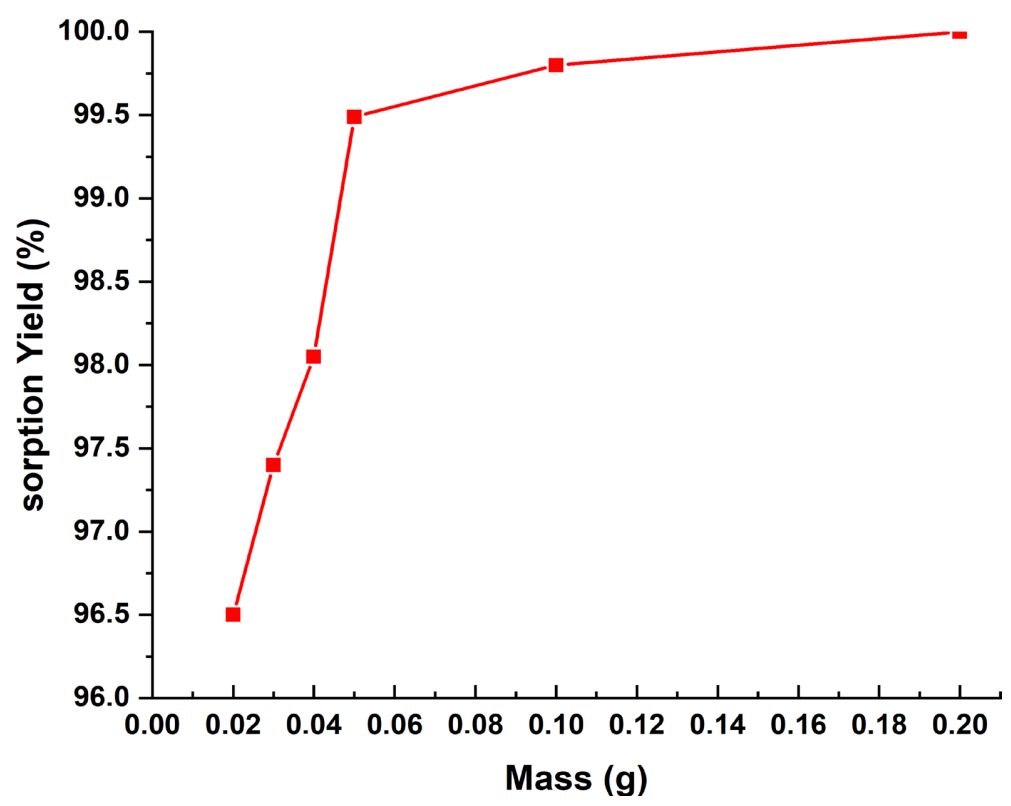

Figure 12. Effect of clay mass on the adsorption of methylene blue. 
yield as a function of the effect of the clay mass. It can be seen that the percentage of the sorption yield of methylene blue molecules increases with the increase of the clay mass until the methylene blue sorption equilibrium is reached by a mass of $0.2 \mathrm{~g}$. All active sites on the adsorbent surface were then occupied, and any increase in adsorbent dosage did not yield a higher methylene blue uptake. An optimal quantity of $0.02 \mathrm{~g}$ for the clay will be necessary to fix the maximum amount of methylene blue.

\subsection{Adsorption Isotherms}

The equilibrium adsorption isotherm is vital to the design of adsorption systems, and its shape provides information about the homogeneity and heterogeneity of the adsorbent surface [30]. It is expressed by relating the amount of adsorbate taken up per gram of adsorbent, ( $\mathrm{mg}^{-\mathrm{g}^{-1}}$ ), to the equilibrium solution concentration, $\left(\mathrm{mg} \cdot \mathrm{l}^{-1}\right)$, at a fixed temperature. In order to evaluate the capacity of adsorption of methylene Blue by the clay of Ouled Bou Sbaa deposit, a study of adsorption isotherms was carried out. Recall that an adsorption isotherm is also called saturation run. Figure 13 represents the equilibrium isotherm of sorption of methylene blue molecules by the clay of Ouled Bou Sbaa.

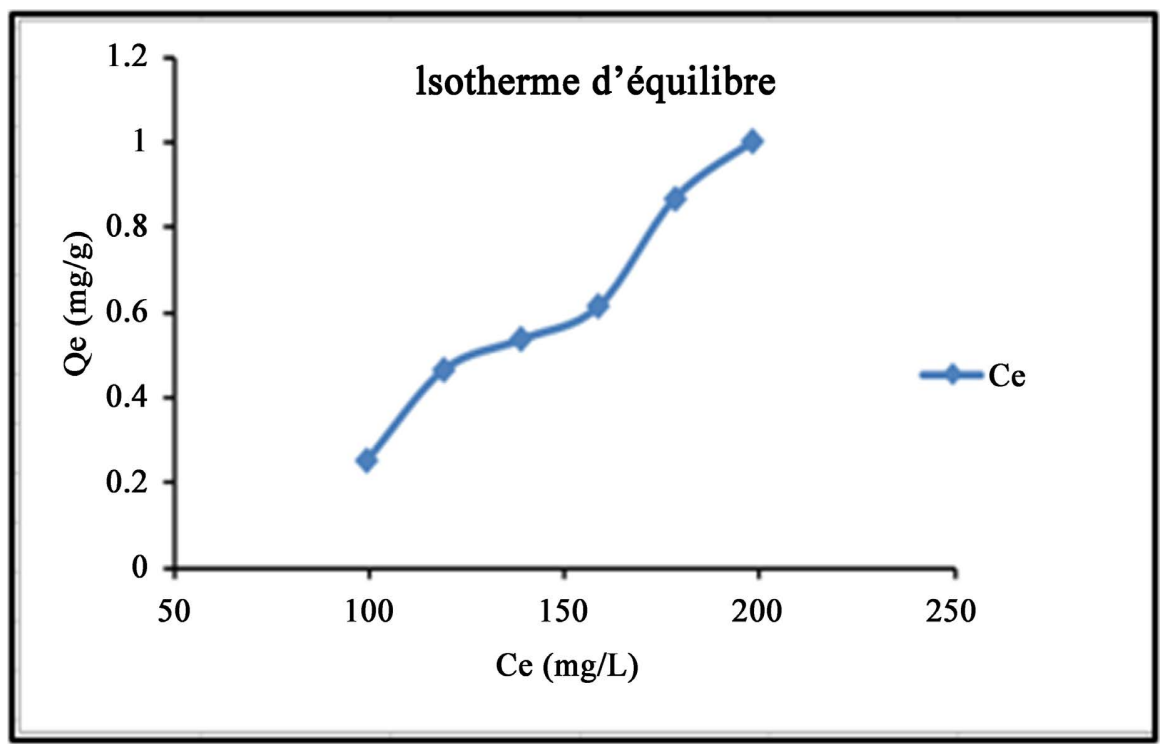

Figure 13. Sorption isotherm of blue of methylene onto clay.

We observe that the adsorption of methylene blue by the Ouled Bou Sbaa clay at low concentration is not significant and is similar to weak adsorbent/adsorbate interactions. For higher concentrations, the amount adsorbed probably increases due to cooperative effects.

To treat the experimental data and explain the obtained equilibrium isotherm, we used several mathematical models: Langmuir, Freundlich and Elovich.

\subsubsection{Langmuir Isotherm}

The Langmuir adsorption isotherm is based on the concept that adsorption is 
localized and results only in the formation of a monolayer. Solid surfaces have finite adsorption sites. When all adsorption sites are filled, the surface is no longer able to adsorb the solute from solution [31].

The equation for the Langmuir isotherm is as follows [32]

$$
C_{e} / Q_{e}=(1 / K L Q m)+C_{e} / Q_{m}
$$

where:

$C_{e}$ : Equilibrium adsorption concentration $(\mathrm{mg} / \mathrm{l})$;

$Q_{e}$ : Quantity adsorbed per gram of clay $(\mathrm{mg} / \mathrm{g})$ at equilibrium;

$Q_{\max }$ The amount of adsorbate adsorbed per unit mass of clay $(\mathrm{mg} / \mathrm{g})$;

$K L$ : Langmuir constant which can be considered a measure of adsorption energy.

\subsubsection{Freundlich Isotherm}

In contrast to the Langmuir model, the Freundlich model assumes that the adsorbent surface energy is heterogeneous. The expression for the Freundlich adsorption isotherm is presented in Equation:

$$
\ln Q_{e}=\ln K F+(1 / n) \cdot \ln C_{e}
$$

where $K F\left(\mathrm{~L} \cdot \mathrm{g}^{-1}\right)$ and $n$ are Freundlich adsorption constants related to the adsorption capacity and intensity of the adsorbents, respectively. The constants were determined by the linear plot of $\operatorname{Ln} Q_{e}$ versus $\operatorname{Ln} C_{e}$.

\subsubsection{Elovich Isotherm}

The relationship of [33] differs from that of Langmuir in the evolution of adsorption sites. The number of available sites varies in this model exponentially during adsorption, which implies a multilayer adsorption. The Elovich isotherm is expressed as:

$$
\operatorname{Ln}\left(Q_{e} / C_{e}\right)=\operatorname{Ln}\left(K E \cdot Q_{m}\right)-Q_{e} / Q_{m}
$$

where $\mathrm{KE}\left(L \cdot \mathrm{mg}^{-1}\right)$ is the Elovich adsorption constant related to the affinity of the surface sites with the adsorbate.

The linear transforms of the Langmuir, Freundlich and Elovich models are shown in Figures 14-16.

The parameters characterizing each linear expression of these models have been determined and are given in Table 2 .

Based on $\mathrm{R}^{2}$, we notice that the values of the empirical coefficient of the three models (Freundlich $\left(\mathrm{R}^{2}=0.95\right)$, Langmuir $\left(\mathrm{R}^{2}=0.92\right)$ and Elovich $\left(\mathrm{R}^{2}=0.80\right)$ ) are comparable. For the Langmuir type adsorption process, the influence of the isotherm shape on the favorability or infavorability of the adsorption can be classified by the separation factor $R L$, which is considered to be a more reliable indicator of the adsorption capacity [34]. This constant is evaluated as:

$$
R L=1 /\left(1+K_{L} C_{0}\right)
$$

where $K_{L}\left(\mathrm{dm}^{3} \cdot \mathrm{mg}^{-1}\right)$ is the Langmuir constant and $C_{0}\left(\mathrm{mg} \cdot \mathrm{dm}^{-3}\right)$ is the initial concentration in the liquid phase. The value of RL indicates the type of the 


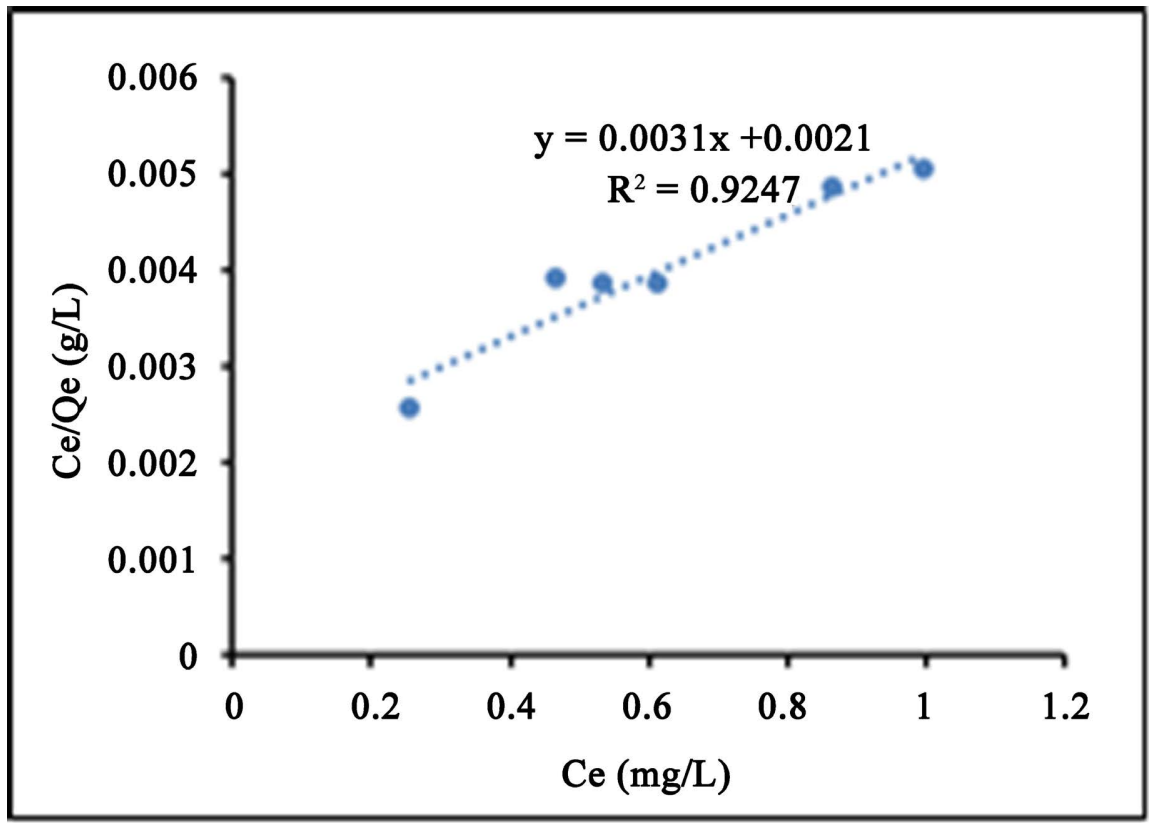

Figure 14. Langmuir isotherm.

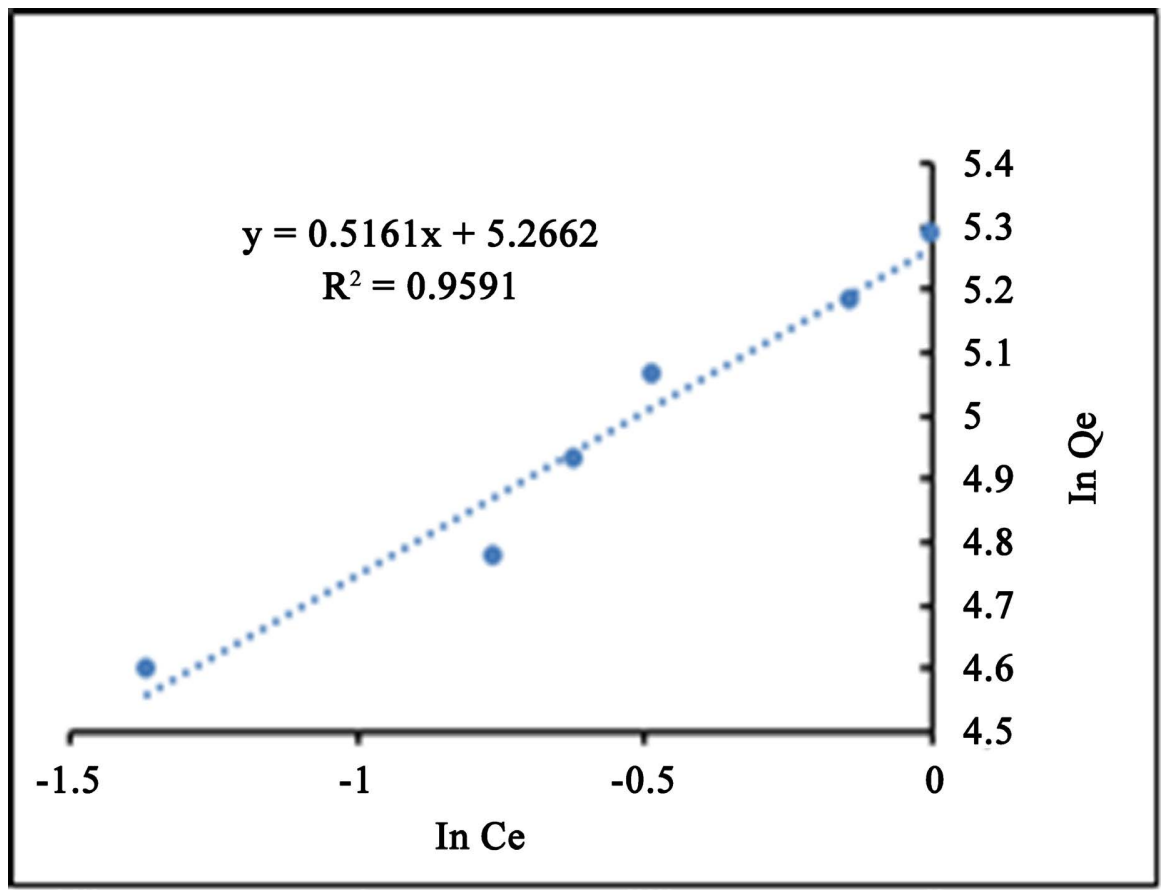

Figure 15. Freundlich isotherm.

isotherm to be unfavorable $(R L>1)$, linear $(R L=1)$, favorable $(0<R L<1)$, or irreversible $(R L=0)$ [35]. The degree of favorability is generally related to the irreversibility of the system, which gives a qualitative assessment of methylene blue-Clay interactions [36]. In the present work, the value of RL calculated is 0.006, indicating that the Langmuir model can describe the adsorption process. The maximum of adsorption estimated from the Langmuir model is 322.58 $\mathrm{mg} / \mathrm{g}$. 


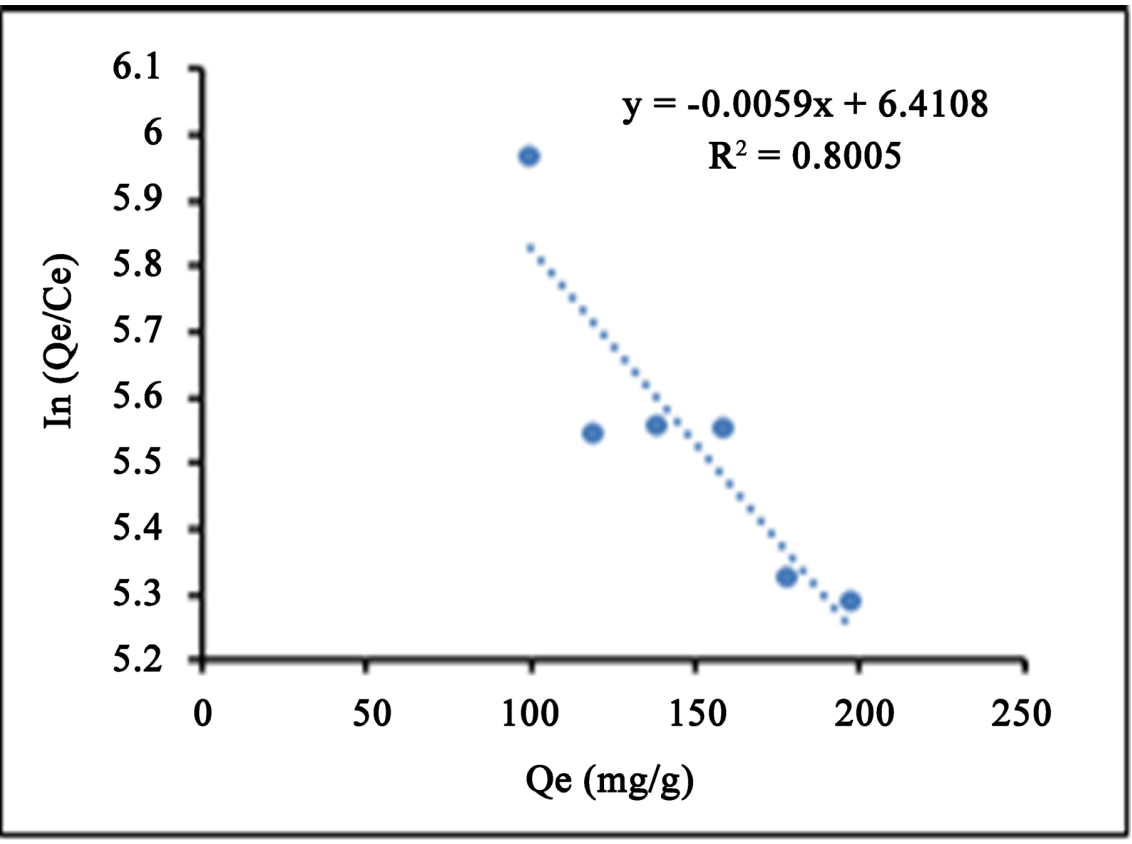

Figure 16. Elovich isotherm.

Table 2. Isotherms parameters models for Blue of methylene adsorption onto the clay.

\begin{tabular}{cccc}
\hline Models & Equation & R2 & Models parameters \\
\hline \multirow{2}{*}{ Langmuir } & $\mathrm{y}=0.0031 \mathrm{x}+0.0021$ & $R^{2}=0.9247$ & $K_{L}=1.48 \mathrm{~L} / \mathrm{mg}$ \\
& & & $Q_{m}=322.58 \mathrm{mg} / \mathrm{g}$ \\
Freundlich & $\mathrm{y}=0.5161 \mathrm{x}+5.2662$ & $R^{2}=0.9591$ & $n=1.9376$ \\
& & & $K_{F}=14.31 \mathrm{~L} / \mathrm{g}$ \\
Elovich & $\mathrm{y}=-0.0059 \mathrm{x}+6.4108$ & $R^{2}=0.8005$ & $Q_{E}=169.49 \mathrm{mg} / \mathrm{g}$ \\
& & & $K_{E}=3.47 \mathrm{~L} / \mathrm{mg}$ \\
\hline
\end{tabular}

The nature of the parameters of the Freundlich $K_{F}$ model, and n obtained as can be seen in Table 2, showed that the adsorption process was favorable $(n>$ 1). The value of the empirical coefficient $R^{2}\left(R^{2}=0.80\right)$ of the Elovich isotherm is revealed that the model tended towards Freundlich and not Langmuir.

\section{Discussion}

The mineralogical and geochemical tests show that the Maastrichtian-Thanetian clay of the Ouled Bou Sbaa (Meskala Basin) contains variable proportions of clay minerals with dominant montmorillonite and palygorskite. The non-clay minerals appear, such as quartz and carbonate fluoroapatite. The proportion and distribution of clay minerals along the phosphate series of the Ouled Bou Sbaa deposit are shown in Figure 6. The clay minerals present in the analyzed samples are montmorillonite $(10 \%-50 \%)$, palygorskite $(5 \%-50 \%)$, sepiolite $(5 \%-30 \%)$ and illite (5\% - 20\%).

In Maastrichtian sediments, montmorillonite is the most dominant clay mineral. Fibrous minerals (palygorskite and sepiolite) are present in similar propor- 
tions from the base to the top of the serie (Figure 6). During the Paleogene, the montmorillonite content decreases, and palygorskite became the most dominant clay mineral during this period. The illite grade is still low. Illite being present as the least abundant mineral in the phosphate series of the Ouled Bou Sbaa deposit.

Several authors have recognized the usual presence of montmorillonite, palygorskite, sepiolite and illite in other Moroccan phosphate deposits: 1) In the Ganntour Basin, the clay fraction consists of a mixture in variable proportions of montomorillonite, palygorskite, sepiolite and illite [37] [38] [39]; 2) In the Upper Cretaceous-Tertiaire formations of the Western High Atlas. Montmorillonite (smectite) dominate the older series, while palygorskite (fibrous clays) the younger beds with some small quantities of sepiolite, and trace amounts of [37] [38] [40]; 3) The clays found in the Ouled Abdoun basin are palygorskite clays, montmorillonite clays and magnesian clays of sepiolite type [41] [42].

Among the objectives of this work, the valorization of the clays of the Moroccan phosphate series in the field of wastewater treatment. Adsorption tests on clay samples from the Ouled Bou Sbaa deposit were carried out using the cationic dye "methylene blue" as a model pollutant. The results showed that the clay can be used as a low cost adsorbent for the removal of cationic dye from wastewater. Nevertheless, adsorption reversibility should be deeply investigated to confirm the efficient of these clays are, and to confirm which surface sites (ion exchange or edge surface) are sufficiently strong to prevent release of cationic dye according to physico-chemical conditions. Adsorption tests of methylene blue in the clays of the Ouled Bou Sbaa deposit have shown that the fixation kinetics are very fast and that these clays have a very high adsorption power compared to other natural sorbents. The evaluation of the Langmuir isotherm model in this study showed that the adsorption process was described by a monolayer coverage of methylene blue on the clay surface although there is a low affinity in the interaction between the adsorbate and the adsorbent [43]; this was revealed by the low value of their correlation coefficient $\mathrm{R}^{2}$ compared to the Freundlich isotherm.

Considering the correlation of the Freundlich coefficient $\left(R^{2}=0.9591\right)$, this model assures heterogeneity, mesoporosity of the support and variation in the number of available sites during adsorption, which implies multilayer adsorption, and predicts that the concentration of dye on the adsorbent will increase with the concentration of the adsorbate in the solution [44]. Also, the n-value calculated by the Freundlich model is 1.032 . The $n$ value greater than 1 demonstrates that the adsorption bond between the adsorbent and the adsorbate is sufficiently strong. The value of $\mathrm{R}^{2}=0.80$ of the Elovich isotherm revealed that the model tended towards Freundlich and not Langmuir and that the adsorption of the clay was not due to a monolayer arrangement, but to ion exchange and complexation interactions resulting from a complete coverage of the surface functional groups of the adsorbent via surface exchange reactions [45]. The compar- 
ison of these results of the sorption of methylene blue by the clay of the deposit of Ouled Bou Sbaa (Meskala basin) with other clays of the Moroccan phosphate series shows that the adsorption of methylene blue by two types of clays of the deposit of Sidi Daoui (basin of Ouled abdoun) is comparable [46].

\section{Conclusions}

The Ouled Bou Sbaa deposit is one of the phosphate deposits of the Meskala basin. This work focused on the characterization and the beneficiation of the intercalated clayey sediments and/or associated with the phosphate deposits of the Ouled Bou Sbaa deposit.

The conclusions to be retained from this work are as follows

- The mineralogical study shows that the clays of the Ouled Bou Sbaa deposit are: montmorillonites, palygorskite, sepiolite and illites. These clay minerals are associated with variable quantities of quartz and carbonate fluorapatites. The infrared spectroscopy results confirm these mineralogies the presence of the characteristic bands of montmorillonites and illites. In Maastrichtian, montmorillonite is the most dominant clay mineral. Fibrous minerals (palygorskite and sepiolite) are present in similar proportions from the base to the top of the series. During the Paleogene, the montmorillonite content decreases, and palygorskite became the most dominant clay mineral during this period. The illite grade is still low. Illite is present as the least abundant mineral in the phosphate series of the Ouled Bou Sbaa deposit.

- Major elements compositions with high silica $\left(\mathrm{SiO}_{2}\right)$, alumina $\left(\mathrm{Al}_{2} \mathrm{O}_{3}\right)$ and iron oxides $\left(\mathrm{Fe}_{2} \mathrm{O}_{3}\right)$ contents fit with the above observations.

- Maastrichtian-Paleogene sediments samples show similar proportions of clay minerals from the base to the top of the series. In Maastrichtian sediments, montmorillonite the most dominant clay mineral, fibrous clay minerals (palygorskite and sepiolite) and illite are present in small quantities. During the Paleogene, the palygorskite became the most dominant at the top of the series.

- The tests for the recovery of our clays in the field of environmental protection as materials for the elimination of toxic dyes and metals from mine and urban site waters have shown that the fixation kinetics are very fast and that these clays have a very high adsorbing power compared to others natural sorbent mentioned in the literatures. The equilibrium data are tested using the Langmuir, Freundlich and Elovich isotherm models, and the best fit is obtained with the Freundlich model.

\section{Acknowledgements}

This work is supported by collaboration between the Dynamics of Sedimentary Basins and Geological Correlations Laboratory, Faculty of Sciences Ben M’Sick, University Hassan II of Casablanca and Direction of Geology of Office Cherifian of Phosphates (OCP). The analyses of X-ray diffraction (XRD), X-ray fluores- 
cence (XRF) and infrared spectroscopy (IR) were carried out respectively at the National Center for Scientific Research and Technical (CNRST) in Rabat, the analysis Center at the Faculty of Science and Technology in Settat and the analysis center at the Faculty of Science Ben M'Sick in Casablanca.

\section{Conflicts of Interest}

The authors declare no conflicts of interest regarding the publication of this paper.

\section{References}

[1] Doğan, M., Özdemir, Y. and Alkan, M. (2007) Adsorption Kinetics and Mechanism of Cationic Methyl Violet and Methylene Blue Dyes onto Sepiolite. Dyes and Pigments, 75, 701-713. https://doi.org/10.1016/j.dyepig.2006.07.023

[2] Allègre, C., Moulin, P., Maisseu, M. and Charbit, F. (2006) Treatment and Reuse of Reactive Dyeing Effluents. Journal of Membrane Science, 269, 15-34. https://doi.org/10.1016/j.memsci.2005.06.014

[3] Srivastava, S., Sinha, R. and Roy, D. (2004) Toxicological Effects of Malachite Green. Aquatic Toxicology, 66, 319-329. https://doi.org/10.1016/j.aquatox.2003.09.008

[4] Rafatullah, M., Sulaiman, O., Hashim, R. and Ahmad, A. (2010) Adsorption of Methylene Blue on Low-Cost Adsorbents: A Review. Journal of Hazardous Materials, 177, 70-80. https://doi.org/10.1016/j.jhazmat.2009.12.047

[5] Bentahar, Y., Hurel, C., Draoui, K., Khairoun, S. and Marmier, N. (2016) Adsorptive Properties of Moroccan Clays for the Removal of Arsenic(V) from Aqueous Solution. Applied Clay Science, 119, 385-392. https://doi.org/10.1016/i.clay.2015.11.008

[6] Christidis, G.E., Scott, P.W. and Dunham, A.C. (1997) Acid Activation and Bleaching Capacity of Bentonites from the Islands of Milos and Chios, Aegean, Greece. Applied Clay Science, 12, 329-347. https://doi.org/10.1016/S0169-1317(97)00017-3

[7] Dias, N., Steiner, P. and Braga, M. (2015) Characterization and Modification of a Clay Mineral Used in Adsorption Tests. Journal of Minerals and Materials Characterization and Engineering, 3, 277-288. https://doi.org/10.4236/jmmce.2015.34030

[8] Li, Z., Chang, P.H., Jiang, W.T., Jean, J.S. and Hong, H. (2011) Mechanism of Methylene Blue Removal from Water by Swelling Clays. Chemical Engineering Journal, 168, 1193-1200. https://doi.org/10.1016/j.cej.2011.02.009

[9] Bagane, M. and Guiza, S. (2000) Removal of a Dye from Textile Effluents by Adsorption. Annales de Chimie Science des Materiaux, 25, 615-625. https://doi.org/10.1016/S0151-9107(00)90003-5

[10] Medina, F. (1995) Syn- and Post-Rift Evolution of the El Jadida-Agadir Basin (Morocco): Constraints for the Rifting Models of the Central Atlantic. Canadian Journal of Earth Sciences, 32, 1273-1291. https://doi.org/10.1139/e95-104

[11] Duffaud, F., Brun, L. and Plauchut, B. (1966) Le bassin du Sud-Ouest marocain. In: Reyre, D., Ed., Bassins sédimentaires du littoral africain, Publication Association Services géologiques africains, Paris, 5-26.

[12] Le Roy, P. (1997) Les bassins ouest marocains, leur formation et leur évolution dans le cadre de l'ouverture et du développement de l'Atlantique central (marge africaine). Thèse de Doctorat, Université de Bretagne Occidentale, Brest, 327 p. 
[13] Hafid, M. (1999) Incidences de l'évolution du Haut Atlas occidental et de son avant pays septentrional sur la dynamique méso-cénozoïque de la marge atlantique (entre Safi et Agadir). Apport de la sismique réflexion et des données de forages. Thèse d’État, Université Ibn Tofail, Faculté Sciences, Kenitra, 282 p.

[14] Zeigler, P.A. (1988) Evolution of the Artic-North Atlantic and the Western Tethys. American Association of Petroleum Geologists Memoir, 43, 198 p.

[15] Ouajhain, B., Daoudi, L. and Medina F. (2009) Contrôle paléogéographique de la sédimentation argileuse du Jurassique du bassin atlasique d'Essaouira (Haut Atlas occidental, Maroc). Comunicaçes Geolgicas, 96, 51-66.

[16] Brindley, G.W. and Brown, G. (1980) Crystal Structures of Clay Minerals and Their X-Ray Identification. Mineralogical Society of Great Britain and Ireland, London, $495 \mathrm{p}$.

[17] Moore, D.M. and Reynolds, R.C. (1989) X-Ray Diffraction and the Identification and Analysis of Clay Minerals. Oxford University Press, New York, 322 p.

[18] Bouras, O. (2003) Propriétés adsorbantes des argiles organiques pontées: synthèse et caractérisation. Thèse de Doctorat, Université de Limoges, Limoges, 160 p.

[19] Hidalgo, C., Bertaux, J. and Quantin, P. (1995) Forms of Silica in Indurated Volcanic Soils of the Mexico Valley. Proceedings of the 10 th International Clay Conference, CSIRO Publishing, Melbourne, 487-493.

[20] Farmer, V.C. (1974) The Layer Silicates. In: Farmer, V.C., Ed., The Infrared Spectra of Minerals Mineralogical Society, Mineralogical Society, London, 331-365.

https://doi.org/10.1180/mono-4.15

[21] Madejova, J., Bujdak, J., Janek, M. and Komadel, P. (1998) Comparative FT-IR Study of the Structural Modifications during Acid Treatment of Dioctahedral Smectites and Hectorite. Spectrochimica Acta Part A, 54, 1397-1406. https://doi.org/10.1016/S1386-1425(98)00040-7

[22] Caillere, S., Henin, S. and Rautrureau, M. (1982) Minéralogie des argiles. Masson, Paris.

[23] Ayari, F., Srasra, E. and Trabelsi-Ayadi, M. (2005) Characterization of Bentonitic Clays and Theiruse as Adsorbent. Desalination, 185, 391-397. https://doi.org/10.1016/j.desal.2005.04.046

[24] Bergaya, F., Theng, B.K.G. and Lagaly, G. (2006) Handbook of Clay Science: Developments in Clay Science, Vol. 1. Elsevier, Amsterdam.

[25] Srasra, E. (1987) Caractérisation minéralogique, propriété physico-chimique et application des argiles du gisement Haidoudi. Thèse de 3ème cycle, Faculté des Science de Tunis, Université Tunis II, Tunis.

[26] Abajo, M. (2000) Manual sobre Fabrication de Baldosas, Tejas y Ladrillos. Beralmar, Barcelona.

[27] Barka, N. (2008) L'élimination des colorants de synthèse par adsorption sur un phosphate naturel et par dégradation supporté photocatalytique sur $\mathrm{TiO}_{2}$. Thèse de Doctorat, $\mathrm{N}^{\circ} 65,40-65$.

[28] Almeida, C.A.P., Debacher, N.A., Downs, A.J., Cottet, L. and Mello, C.A.D. (2009) Removal of Methylene Blue from Colored Effluents by Adsorption on Montmorillonite Clay. Journal of Colloid and Interface Science, 332, 46-53. https://doi.org/10.1016/j.jcis.2008.12.012

[29] Hajjaji, W., Andrejkovicova, S., Pullar, R.C., Tobaldi, D.M., Lopez-Galindo, A.F., Jammoussi Rocha, F. and Labrincha, J.A. (2016) Effective Removal of Anionic and Cationic Dyes by Kaolinite and $\mathrm{TiO}_{2} /$ Kaolinite Composites. Clay Minerals., 51, 
19-27.

[30] Arami, M., Yousefi Limaee, N., Mahmoodi, N.M. and Salman Tabrizi, N. (2006) Equilibrium and Kinetics Studies for the Adsorption of Direct and Acid Dyes from Aqueous Solution by Soy Meal Hull. Journal of Hazardous Materials, 135, 171-179. https://doi.org/10.1016/j.jhazmat.2005.11.044

[31] Langmuir, I. (1916) The Constitution and Fundamental Properties of Solids and Liquids. Part I. Solids. Journal of the American Chemical Society, 38, 2221-2295. https://doi.org/10.1021/ja02268a002

[32] Langmuir, I. (1918) The Adsorption of Gases on Plane Surface of Glass, Mica and Platinum. Journal of the American Chemical Society, 40, 1361-1403.

https://doi.org/10.1021/ja02242a004

[33] Elovich, S.Y. and Larinov, O.G. (1962) Theory of Adsorption from Solutions of Non Electrolytes on Solid (I) Equation Adsorption from Solutions and the Analysis of Its Simplest Form, (II) Verification of the Equation of Adsorption Isotherm from Solutions. Izvestiya Akademii Nauk SSSR, Otdelenie Khimicheskikh Nauk, 2, 209-216.

[34] Hall, K.R., Eagleton, L.C., Acrivos, A. and Vermeulen, T. (1966) Pore- and Solid-Diffusion Kinetics in Fixed Bed Adsorption under Constant Pattern Conditions. Industrial \& Engineering Chemistry Fundamentals, 5, 212-223. https://doi.org/10.1021/i160018a011

[35] Baskaralingam, P., Pulikesi, M., Elango, D., Ramamurthi, V. and Sivanesan S. (2006) Adsorption of Acid Dye onto Organobentonite. Journal of Hazardous Materials, 128, 138-144. https://doi.org/10.1016/j.jhazmat.2005.07.049

[36] Gupta, V.K., Rastogi, A., Saini, V.K. and Jain, N. (2006) Biosorption of Copper(II) from Aqueous Solutions by Spirogyra Species. Journal of Colloid and Interface Science, 296, 59-63. https://doi.org/10.1016/j.jcis.2005.08.033

[37] Boujo, A. (1976) Contribution à l'étude géologique du gisement de phosphate Crétacé -Eocène des Gantour (Maroc occidental). Notes et Mémoires Service Géologique Maroc, $227 \mathrm{p}$.

[38] Prévot, L., Boujo, A. and Lucas, J. (1971) Etude minéralogique de la série phosphatée des Gantour (Maroc). Sciences Géologiques, Bulletins et Mémoires, 24, 243-253. https://doi.org/10.3406/sgeol.1971.1394

[39] Mouflih, M. (1991) La série phosphatée du gisement de Benguerir séquences de faciès, évolution séquentielle, minéralogie et géochimie (Maastrichtien-lutétien). Thèse de 3ème cycle, Université Cadi Ayyad, Marrakech, 246 p.

[40] Daoudi, L., Rocha, F., Ouajhain, B., Dinis, J.L., Chafiki, D. and Callapez, P. (2008) Palaeoenvironmental Significance of Clay Minerals in Upper Cenomanian-Turonian Sediments of the Western High Atlas Basin (Morocco). Clay Minerals, 432, 615-630.

[41] Jeannette, D., Moniton, A., Ortelli, L. and Salvan, H. (1956) Premiers résultats de l'étude des argiles de la série phosphatée du bassin de Khouribga (Maroc). 20ème Congrès International de Géologie-Mexico, Mexico City, September 1956, 52-60.

[42] Crayeux, L. (1950) Les phosphates de chaux sédimentaires de la France métropolitaine et d'Outre-mer; t.I, France; t.II, Algérie_Tunisie; t.III, Maroc-Afrique noire. Publication dans le service de la carte géologique de la France, Paris.

[43] Hameed, B.H. and Hakimi, H. (2008) Utilization of Durian (Durio zibethinus Murray) Peel as Low Cost Sorbent for the Removal of Acid Dye from Aqueous Solution. Biochemical Engineering Journal, 39, 338-343.

https://doi.org/10.1016/j.bej.2007.10.005

[44] Freundlich, H.M.F. (1906) Über Die Adsorption in Lösungen. Zeitschrift für Physi- 
kalische Chemie, 57, 385-470. https://doi.org/10.1515/zpch-1907-5723

[45] Toor, M. and Jin, B. (2012) Adsorption Characteristics, Isotherm, Kinetics, and Diffusion of Modified Natural Bentonite for Removing Diazo Dye. Chemical Engineering Journal, 187, 79-88. https://doi.org/10.1016/j.cej.2012.01.089

[46] Jahroud, N. (2009) Valorisation des fractions argileuses des produits miniers phosphatés comme matériaux de dépollution des eaux contaminées par les métaux lourds et les colorants. Thèse de Doctorat, Université Hassan II Mohammedia Casablanca, Faculté des Sciences Ben M'Sik, 126 p. 